\title{
Effect of INM Practices on Yield, Yield Attributes and Economics of Coriander (Coriandrum sativum L.)
}

\author{
Priyadarshini Jhankar $^{1^{*}}$, C.M. Panda ${ }^{1}$ and Debadatta Sethi ${ }^{2}$ \\ ${ }^{1}$ Department of Vegetable Science, O. U. A. T., Bhubaneswar, India \\ ${ }^{2}$ Department of Soil Science and Agricultural Chemistry, O. U. A. T., Bhubaneswar, India \\ *Corresponding author
}

\begin{tabular}{|c|c|}
\hline & A B S T R A C T \\
\hline & The experiment was conducted during two Rabi seasons of the year 2015-17 at the \\
\hline Keywords & $\begin{array}{l}\text { experimental site of the Department of Horticulture, College of Agriculture, O. U. A. T., } \\
\text { Bhubaneswar. Combination of bio-fertilizers (Azotobacter+ Azospirillum+ PSB) }\end{array}$ \\
\hline $\begin{array}{l}\text { Biofertilizer, } \\
\text { Coriander, }\end{array}$ & $\begin{array}{l}\text { inorganic fertilizers + FYM gave better performance as compared to only bio-fertilizers } \\
\text { (Azotobacter+ Azospirillum+ PSB)/ organic manure/ inorganic fertilizers and other }\end{array}$ \\
\hline Integrated Nutrient & combinations. The treatment results a soil application of inorganic fertilizers $(100 \%$ of \\
\hline $\begin{array}{l}\text { Management, } \\
\text { PSB, FYM, Yield. }\end{array}$ & $\begin{array}{l}\text { RDF) with bio-fertilizers ( Azotobacter+ Azospirillum+ PSB) @ } 2.5 \mathrm{~kg} \mathrm{ha}^{-1} \text { and FYM @ } 5 \\
\mathrm{t} \mathrm{ha}{ }^{-1} \text { which resulted the maximum plant height }(26.93 \mathrm{~cm}) \text {, number of primary branches }\end{array}$ \\
\hline Article Info & $\begin{array}{l}\text { per plant }(6.93) \text {, number of compound leaves per plant }(38.74) \text {, yield }\left(8.0 \mathrm{t} \mathrm{ha}^{-1}\right) \text { followed } \\
\text { by the soil application of inorganic fertilizer }(75 \% \text { of RDF })+\text { bio-fertilizers }(\text { Azotobacter+ }\end{array}$ \\
\hline $\begin{array}{l}\text { Accepted: } \\
\text { 12 April } 2017 \\
\text { Available Online: } \\
10 \text { May } 2017\end{array}$ & $\begin{array}{l}\text { Azospirillum+ PSB) @ } 2.5 \mathrm{~kg} \mathrm{ha}^{-1}+\mathrm{FYM} @ 5 \mathrm{t} \mathrm{ha}^{-1} \text { with respect to plant height }(26.14 \\
\mathrm{cm}) \text {, number of primary branches per plant }(6.53) \text { and herbage yield }\left(7.8 \mathrm{th}^{-1}\right) \text {. Regarding } \\
\text { economics of the experiment, the maximum net profit Rs. } 10769 \mathrm{ha}^{-1} \text { and benefit : cost } \\
\text { (2.09) were computed in the treatment having a soil application of inorganic fertilizer }\end{array}$ \\
\hline & $\begin{array}{l}\text { (100\% of RDF) + Biofertilizers (Azotobacter+ Azospirillum+ PSB)@ } 2.5 \mathrm{~kg} \mathrm{ha}^{-1}+\text { FYM } \\
@ 5 \mathrm{tha}^{-1} \text {. }\end{array}$ \\
\hline
\end{tabular}

\section{Introduction}

Coriander (Coriandrum sativum L.), a widely grown condiment crop of the tropics is very popular from cuisines to food court. India is the largest producer of coriander both in terms of area (547421 ha) and production (527390 tonnes). It is not only used for culinary purposes but also as a condiment as well as a nutraceutical. It is an herbaceous annual member of Apiaceae family under the order Apiales. Coriander requires cool climate during vegetative growth stage and warm dry climate at flowering. It can be cultivated in all most all types of soils but in well drained loamy soil it flourishes well. The quality of seed is superior and essential oil content is more when the crop is grown in cooler regions and at higher altitudes. The stems, leaves, and seeds of coriander are used in a number of culinary preparations. The green plant in India is used in soups, salads and chutneys (Ilyas, 1980). The name "cilantro" is frequently used in American English to refer to the green herb or the dried leaves of coriander (Lamberts, 1990). Considering the organic production which is gaining momentum at present, the use of bio- 
fertilizers has attained a special significance in crop husbandry to address the sustainability problem and tremendous success has been achieved in this crop. As a thumb rule the higher productivity could be determined by selection of suitable varieties, balance nutrition, optimum water management and timely plant protection measures. In recent years, bio-fertilizers acquired a potential position in horticulture, but scanty information is available on bio- fertilizer use especially in coriander.

Application of bio-fertilizers such as PSB, Azotobacter, Azospirillum has reduced the use of chemical fertilizers but provided high quality organic products free of harmful agrochemicals for the safety of public health (Salem and Awad, 2005; Mahfouz and Sharaf Eldin, 2007). The fertility status of soil is not that high suffice the entire nutrient demand of the crop. Hence, external supply of nutrients through manure and fertilizers has become the need of the hour. Therefore, a balance fertilizer dosage with FYM, vermicompost and bio-fertilizer as per the crop type needs to be standardized which facilitates to calculate the entire nutrient requirement of the crop throughout its gestation period which culminating to a bumper yield. Standardization of genotypes for their performance in different locations with varied cultural practices for an overall increase in the yield in one hand and generating a good economic return to the farmer in other hand is most important.

\section{Materials and Methods}

The field experiment was conducted under irrigated condition during Rabi 2015-16 and repeated in 2016-17 at the demonstration plot of the Department of Vegetable Science, College of Agriculture. OUAT, Bhubaneswar, which is situated at $22^{0} 15^{\prime}$ North latitude, $80^{\circ}$ 22 East longitude and in an altitude of $25.5 \mathrm{~m}$ above the mean sea level (MSL). It comes under eastern coastal part of Odisha. Soil of the experimental site was medium clay soil. Before the initiation of the experiment the soil samples were collected and analyzed for the physical and chemical characteristics by following different standard methods.

The experimental soil had sandy loam in texture by following Bouyoucos hydrometer method (Piper,1966)) having $5.1 \mathrm{mg} \mathrm{kg}^{-1}$ organic carbon, $\mathrm{KMnO}_{4}$ extractable $\mathrm{N}-246 \mathrm{~kg}$ $\mathrm{ha}^{-1}$, Olsen's P-20 kg ha ${ }^{-1}$ and $1 \mathrm{~N}$ ammonium acetate extractable $\mathrm{K}-380 \mathrm{~kg} \mathrm{ha}^{-1}$ (Page et al.,1982) The experiment consisted of 10 treatments viz fertility levels $100 \%$ RDF (N$60, \mathrm{P}-40, \mathrm{~K}-20 \mathrm{~kg} \mathrm{ha}^{-1}$ ) supplied as inorganic fertilizer, 50\% RDF through inorganic sources and its combinations with FYM @ 5 tonnes ha ${ }^{-1}$. Azotobacter $2.5 \mathrm{~kg} \mathrm{ha}^{-1}$, PSB @ $2.5 \mathrm{~kg} \mathrm{ha}^{-1}$ in sole application and their combinations with control, the experiment was laid out in 3 replications. The FYM @ 5 tonnes $\mathrm{ha}^{-1}$ was incorporated in to soil, 15 days before sowing of coriander crop. Coriander variety Surabhi was sown during November 2016 and 2016 at $30 \mathrm{~cm}$ row spacing apart. Soil fertility was characterized on the basis of N.P.K in soil for control treatment since the data followed the homogeneity test, pooling was done over the seasons and mean data were interpreted.

The data collected from the experiment were analyzed statistically by following the procedure described by Gomez (1984). The level of significance used in " $F$ " and " $t$ " tests was considered at $\mathrm{P}=0.05$ level. Critical difference values were calculated where ever the $\mathrm{F}$ test was significant.

\section{Results and Discussion}

The biometric observations of different characters were recorded to study the effect of integrated nutrient management practices on morphomatrix and yield attributes of coriander (Tables 1-3). 
A perusal of the detailed data revealed that, there was no significant difference among all the treatment combinations with respect to germination and there was more than $90 \%$ of germination in all plots.

Further, was revealed that, application of different doses of fertilizer, FYM, and biofertilizer influenced the plant height significantly. The highest mean for plant height was obtained in treatment $\mathrm{T}_{8}(26.93$ $\mathrm{cm})$ which was at par with $\mathrm{T}_{7}(26.14 \mathrm{~cm})$ and $\mathrm{T}_{6}(25.35 \mathrm{~cm})$ but differed significantly from $\mathrm{T}_{3}(20.44 \mathrm{~cm}), \mathrm{T}_{5}(16.57 \mathrm{~cm}), \mathrm{T}_{2}(14.11 \mathrm{~cm})$, $\mathrm{T}_{4}(11.64 \mathrm{~cm})$ this may be due to the synergistic effect of inorganic and organic fertilizer which is in agreement with Sahu et al., (2014), Tripathi et al., (2013) and Hamte et al., (2013). The lowest value was recorded in the treatment $\mathrm{T}_{1}(11.00 \mathrm{~cm})$ i.e. control which was at par with $T_{4}$ where biofertilizers were applied $(11.64 \mathrm{~cm})$ it may be due to nutrient mineralizing capacity of Azotobacter, Azospirllum and PSB. However the treatments were in an increasing trend with a maximum plant height $(26.93 \mathrm{~cm})$ in $\mathrm{T}_{8}$ and minimum in control $\mathrm{T}_{1}(11.00 \mathrm{~cm})$, according to the present analysis, integrated application of biofertilizers with inorganic fertilizers have increased plant height by enhancing the nitrogen content and the rate of photosynthesis which is in agreement with (Migahed et al., 2004; Choudhary et al., 2004).

The numbers of primary branches per plant were not varied significantly among the treatments. Maximum numbers of primary branches per plant were recorded in $\mathrm{T}_{8}$ (6.93) which was at par with the treatments $\mathrm{T}_{7}$ (6.53), $\mathrm{T}_{6}$ (6.10), $\mathrm{T}_{3}$ (5.8), $\mathrm{T}_{2}$ (4.40), $\mathrm{T}_{4}(4.07)$ and differed significantly from control $\mathrm{T}_{1}$ (3.93). However the treatments were in an increasing trend with a maximum number of primary branches per plant (6.93) in $\mathrm{T}_{8}$ and minimum in control $\mathrm{T}_{1}$ (3.93).
This study found that a combine application of farm yard manure, inorganic fertilizer and biofertilizer showed a significant deference of number of primary branches per plant in comparison to other treatments (Tripathi et al., 2013; Nagar et al., 2010).

The application of different combinations of NPK, FYM and biofertilizer significantly influenced the number of compound leaves of coriander. Maximum number of compound leaves per plant were recorded with the treatment $\mathrm{T}_{8}$ (38.74) which was at par with the treatments $\mathrm{T}_{7}(38.12)$ and $\mathrm{T}_{6}$ (37.56) and differs significantly from $\mathrm{T}_{3}$ (33.52), $\mathrm{T}_{5}$ (30.57), $\mathrm{T}_{2}$ (28.00), $\mathrm{T}_{4}$ (23.12) and the minimum was recorded in control $\mathrm{T}_{1}$ (17.04).

Maximum mean leaf area was recorded with treatment $\mathrm{T}_{8}\left(156.46 \mathrm{~cm}^{2}\right)$ which was at par with the treatments $\mathrm{T}_{7}\left(155.66 \mathrm{~cm}^{2}\right), \mathrm{T}_{6}$ (154.96) and differed significantly from $\mathrm{T}_{3}$ $\left(142.940 \mathrm{~cm}^{2}\right), \mathrm{T}_{5}\left(128.00 \mathrm{~cm}^{2}\right), \mathrm{T}_{2}(114.00$ $\mathrm{cm}^{2}$ ) and the minimum leaf area was recorded in treatment $T_{1}\left(77.67 \mathrm{~cm}^{2}\right)$ which happened to be the control. The inorganic fertilizer application increased leaf area in comparison to other treatments, which may be due to the effect of adequate amount of nitrogen probably present in experimental site. Similar results reported by Nagar et al., (2010).

\section{Effect of INM practices on yield attributes}

The fresh leaf weight of coriander was significantly influenced by different treatments as in table 2 .

The highest mean, fresh leaf weight $\mathrm{ha}^{-1}$ was recorded in treatment $\mathrm{T}_{8}(6.06 \mathrm{t})$ which was at par with $\mathrm{T}_{7}$ (5.86t), $\mathrm{T}_{6}(5.60 \mathrm{t})$ but differed significantly from $T_{3}(4.52 t), T_{5}(3.59 t), T_{2}$ (2.60t), $\mathrm{T}_{4}(1.79 \mathrm{t})$ and the lowest value was recorded in $\mathrm{T}_{1}$ i.e. $0.79 \mathrm{t} \mathrm{ha}^{-1}$ (Kumar et al., 2009. 
Table.1 Effect of INM practices on growth parameters

\begin{tabular}{|c|c|c|c|c|c|c|c|}
\hline Treatments & $\begin{array}{c}\text { Germination } \\
(\%)\end{array}$ & $\begin{array}{l}\text { Plant } \\
\text { height } \\
(\mathrm{cm})\end{array}$ & $\begin{array}{c}\text { No. of } \\
\text { primary } \\
\text { branches } \\
\text { plant }^{-1}\end{array}$ & $\begin{array}{c}\text { No. of } \\
\text { compound } \\
\text { leaf } \\
\text { plant }^{-1}\end{array}$ & $\begin{array}{r}\text { Leaf } \\
\text { area } \\
\left(\mathrm{cm}^{2}\right)\end{array}$ & $\begin{array}{c}\text { Chlorophyll } \\
\text { content } \\
\text { (spad value) }\end{array}$ & $\begin{array}{l}\text { Leaf Yield } \\
\quad(\mathrm{t} / \mathrm{ha})\end{array}$ \\
\hline $\mathrm{T}_{1}=$ Control. $\left(\mathrm{N}_{\mathrm{O}} \mathrm{P}_{0} \mathrm{~K}_{0}\right.$ And $\left.\mathrm{FYM}_{0}\right)$ & 95.00 & 11.00 & 3.93 & 17.04 & 077.67 & 0.98 & 1.66 \\
\hline $\mathrm{T}_{2}=\mathrm{FYM} @ 5 \mathrm{t} / \mathrm{ha}$ alone. & 95.04 & 14.11 & 4.40 & 32.47 & 114.00 & 1.46 & 3.14 \\
\hline $\mathrm{T}_{3}=\mathrm{RDF}(100 \%)$ & 95.33 & 20.44 & 5.80 & 35.47 & 142.94 & 2.24 & 5.26 \\
\hline $\begin{array}{l}\mathrm{T}_{4}=\text { Biofertilizers } \\
\quad(\text { Azotobacter }+ \text { Azospirillum+ PSB })\end{array}$ & 95.00 & 11.64 & 4.07 & 23.71 & 100.67 & 1.34 & 2.59 \\
\hline $\begin{aligned} \mathrm{T}_{5}= & \mathrm{FYM}+\text { Biofertilizers } \\
& (\text { Azotobacter+ Azospirillum+ PSB })\end{aligned}$ & 95.00 & 16.57 & 5.10 & 31.05 & 128.00 & 1.81 & 4.32 \\
\hline $\begin{array}{r}\mathrm{T}_{6}=\mathrm{FYM}+\mathrm{RDF}(50 \%)+\text { Biofertilizers } \\
\quad(\text { Azotobacter+ Azospirillum+ PSB })\end{array}$ & 95.37 & 25.35 & 6.10 & 37.56 & 154.96 & 2.46 & 7.19 \\
\hline $\begin{array}{l}\mathrm{T}_{7}=\mathrm{FYM}+\mathrm{RDF}(75 \%)+\text { Biofertilizers } \\
\quad(\text { Azotobacter+ Azospirillum+ PSB) }\end{array}$ & 95.67 & 26.14 & 6.53 & 38.12 & 155.66 & 2.55 & 7.80 \\
\hline $\begin{aligned} \mathrm{T}_{8}= & \mathrm{FYM}+\mathrm{RDF}(100 \%)+\text { Biofertilizers } \\
& (\text { Azotobacter+ Azospirillum+ PSB })\end{aligned}$ & 95.67 & 26.93 & 6.93 & 38.74 & 156.46 & 2.62 & 8.00 \\
\hline $\mathrm{CD}(0.05)$ & 01.55 & 02.16 & 0.49 & 03.02 & 011.97 & 0.06 & 0.62 \\
\hline CV\% & 00.93 & 06.50 & 5.24 & 05.61 & 005.32 & 1.88 & 6.82 \\
\hline
\end{tabular}


Table.2 Effect of integrated nutrient management on fresh weight of coriander

\begin{tabular}{|c|c|c|c|c|}
\hline \multirow[t]{2}{*}{ Treatments } & \multicolumn{2}{|c|}{ Fresh Weight $\left(\right.$ ton $\left.\mathrm{ha}^{-1}\right)$} & \multicolumn{2}{|c|}{ Dry weight $\left(\right.$ ton ha $\left.^{-1}\right)$} \\
\hline & Leaf & Total Plant & Leaf & Total Plant \\
\hline $\mathrm{T}_{1}=$ Control. $\left(\mathrm{N}_{\mathrm{O}} \mathrm{P}_{0} \mathrm{~K}_{0}\right.$ And $\left.\mathrm{FYM}_{0}\right)$ & 00.79 & 1.66 & 0.01 & 0.35 \\
\hline $\mathrm{T}_{2}=\mathrm{FYM} @ 5$ tha $^{-1}$ alone. & 02.60 & $3.46(108.0)$ & 0.24 & 0.42 \\
\hline $\mathrm{T}_{3}=\mathrm{RDF}(100 \%)$ & 04.52 & $5.26(216.0)$ & 0.44 & 0.59 \\
\hline $\begin{array}{l}\mathrm{T}_{4}=\text { Biofertilizers } \\
\quad(\text { Azotobacter }+ \text { Azospirillum }+ \text { PSB })\end{array}$ & 01.79 & $2.59(056.0)$ & 0.23 & 0.39 \\
\hline $\begin{aligned} \mathrm{T}_{5}= & \mathrm{FYM}+\text { Biofertilizers } \\
& \quad(\text { Azotobacter }+ \text { Azospirillum }+\mathrm{PSB})\end{aligned}$ & 03.59 & $4.32(106.0)$ & 0.37 & 0.48 \\
\hline $\begin{array}{r}\mathrm{T}_{6}=\mathrm{FYM}+\mathrm{RDF}(50 \%)+\text { Biofertilizers } \\
(\text { Azotobacter }+ \text { Azospirillum }+\mathrm{PSB})\end{array}$ & 05.60 & $7.19(333.0)$ & 0.55 & 0.74 \\
\hline $\begin{array}{r}\mathrm{T}_{7}=\mathrm{FYM}+\mathrm{RDF}(75 \%)+\text { Biofertilizers } \\
(\text { Azotobacter }+ \text { Azospirillum }+\mathrm{PSB})\end{array}$ & 05.86 & $7.80(369.8)$ & 0.58 & 0.77 \\
\hline $\begin{aligned} \mathrm{T}_{8}= & \mathrm{FYM}+\mathrm{RDF}(100 \%)+\text { Biofertilizers } \\
& (\text { Azotobacter }+ \text { Azospirillum }+\mathrm{PSB})\end{aligned}$ & 06.06 & $8.00(381.9)$ & 0.60 & 0.79 \\
\hline $\mathrm{CD}(0.05)$ & 00.79 & 0.62 & 0.05 & 0.07 \\
\hline $\mathrm{CV}(\%)$ & 75.85 & 6.82 & 1.06 & 0.86 \\
\hline
\end{tabular}

Table.3 Effect of INM practices on economics

\begin{tabular}{|c|c|c|c|c|}
\hline Treatments & $\begin{array}{c}\text { Cost of } \\
\text { cultivation } \\
\text { (Rs.) }\end{array}$ & $\begin{array}{c}\text { Gross } \\
\text { return } \\
\text { (Rs.) }\end{array}$ & $\begin{array}{l}\text { Net profit } \\
\quad \text { (Rs.) }\end{array}$ & $\mathrm{B}: \mathrm{C}$ \\
\hline $\mathrm{T}_{1}=$ Control. $\left(\mathrm{N}_{\mathrm{O}} \mathrm{P}_{0} \mathrm{~K}_{0}\right.$ And $\left.\mathrm{FYM}_{0}\right)$ & 20375 & 33200 & 12200 & 0.63 \\
\hline $\mathrm{T}_{2}=\mathrm{FYM} @ 5$ tha $^{-1}$ alone & 40875 & 69200 & 28325 & 0.69 \\
\hline $\mathrm{T}_{3}=\mathrm{RDF}(100 \%)$ & 44855 & 105200 & 60345 & 1.34 \\
\hline $\begin{array}{l}\mathrm{T}_{4}=\text { Biofertilizers } \\
\quad(\text { Azotobacter }+ \text { Azospirillum }+ \text { PSB })\end{array}$ & 33915 & 51800 & 17885 & 0.52 \\
\hline $\begin{aligned} \mathrm{T}_{5}= & \mathrm{FYM}+\text { Biofertilizers } \\
& (\text { Azotobacter+ Azospirillum+ PSB })\end{aligned}$ & 41415 & 86400 & 44985 & 1.08 \\
\hline $\begin{array}{r}\mathrm{T}_{6}=\mathrm{FYM}+\mathrm{RDF}(50 \%)+\text { Biofertilizers } \\
(\text { Azotobacter+ Azospirillum+ PSB })\end{array}$ & 46863 & 143800 & 96937 & 2.06 \\
\hline $\begin{array}{r}\mathrm{T}_{7}=\mathrm{FYM}+\mathrm{RDF}(75 \%)+\text { Biofertilizers } \\
\quad(\text { Azotobacter+ Azospirillum+ PSB) }\end{array}$ & 49587 & 156000 & 106413 & 2.14 \\
\hline $\begin{aligned} \mathrm{T}_{8}= & \mathrm{FYM}+\mathrm{RDF}(100 \%)+\text { Biofertilizers } \\
& (\text { Azotobacter+ Azospirillum+ PSB })\end{aligned}$ & 52311 & 160000 & 10769 & 2.09 \\
\hline
\end{tabular}




\section{Fresh plant weight per hectare}

During the field trial, application of different combinations of fertilizer and other amendments significantly influenced the herbage yield of the plants per hectare (Table $2)$. The highest mean fresh weight $\mathrm{ha}^{1}$ was recorded in treatment $\mathrm{T}_{8}(8$ ton) which was at par with $\mathrm{T}_{7}$ (7.80ton) and significantly differed from $\mathrm{T}_{6}$ (7.19 ton), $\mathrm{T}_{3}$ (5.26 ton), $\mathrm{T}_{5}$ (4.32 ton), $\mathrm{T}_{2}$ (5.26 ton), and $\mathrm{T}_{4}$ (2.59 ton). The $\mathrm{T}_{1}$ (control) recorded the lowest mean fresh plant weight of 1.66 ton $\mathrm{ha}^{-1}$. The data further revealed that on fresh weight basis, the herbage yield plot receiving combination treatment of $\mathrm{T}_{8}$ showed $381.9 \%$ more over control. Similar finding have been reported by Kumar et al., (2009) about the effects of $\mathrm{N}$ fertilizer $(0,30,60$ or $90 \mathrm{~kg} / \mathrm{ha})$ and biofertilizers (Azotobacter, Azospirillum and Azotobacter + Azospirillum) on the yield and quality of coriander (cv. RCr-435). The application of $\mathrm{N}$ up to $60 \mathrm{~kg} / \mathrm{ha}$ significantly increased the plant weight.

The dry leaf weight of coriander varied significantly due to varied combinations of nutrient application and other amendments. The maximum dry leaf weight $\mathrm{ha}^{-1-}$ was recorded in $\mathrm{T}_{8}(0.60 \mathrm{t})$ which is at par with $\mathrm{T}_{7}$ $(0.58 \mathrm{t}), \mathrm{T}_{6}(0.55 \mathrm{t})$ and differed significantly from $\mathrm{T}_{3}(0.44 \mathrm{t}), \mathrm{T}_{5}(0.037 \mathrm{t}), \mathrm{T}_{2}(0.24 \mathrm{t}), \mathrm{T}_{4}$ $(0.23 \mathrm{t})$ and the lowest was recorded in $\mathrm{T}_{1}$ (0.01 t) i.e. control.

\section{Effect of INM practices on dry plant weight}

The highest dry plant weight ha ${ }^{-1}$ of 0.79 ton was recorded in $\mathrm{T}_{8}$ treatment which is at par with $\mathrm{T}_{7}(0.77 \mathrm{t}), \mathrm{T}_{6}(0.74 \mathrm{t})$ and significantly differs from $\mathrm{T}_{3}(0.59 \mathrm{t}), \mathrm{T}_{5}(0.48 \mathrm{t}), \mathrm{T}_{2}(0.42$ ton), $\mathrm{T}_{4}(0.39 \mathrm{t})$ and the lowest mean dry plant weight $\mathrm{ha}^{-1}$ of 0.35 ton was recorded in $\mathrm{T}_{1}$ i.e. control. However the treatments are in an increasing trend with a maximum dry leaf weight in $\mathrm{T} 8(0.6 \mathrm{t})$ and minimum in control T1 (0.01t). Effect of biofertilizer on the dry weight of plant was due to increased nitrogen uptake and the growth rate improvement (Mahfouz and Sharaf Eldin, 2007). The result of present work agrees with the reports of Kumar et al., (2009) on Artemisia pallens and Valadabadi and Farahani (2011) on Nigella sativa.

\section{Effect of INM practices on economics}

The economic feasibility of the biofertilizer treatments indicated that, the $\mathrm{B}: \mathrm{C}$ ratio of the treatments $T_{7}$ and $T_{8}$ has got the highest value2.14 and 2.09 respectively followed by $\mathrm{T}_{6}$ (2.06). Highest $\mathrm{B}: \mathrm{C}$ ratio was obtained as 2.14 in case of FYM + RDF (75\%) + biofertilizers (Azotobacter+ Azospirillum+ PSB) (2.14) and 2.06 in the case of FYM + $\mathrm{RDF}(50 \%)+$ biofertilizers (Azotobacter+ Azospirillum + PSB), which indicates that the substitution of inorganic fertilizer with biofertilizers and FYM resulted at par yield with the use of FYM+RDF(100\%)+ biofertilizers (Azotobacter+ Azospirillum+ PSB). But there was cost saving on the use of inorganic fertilizer up to a tune of $50 \%$.

In conclusion the results revealed that the highest plant height, no of branches, herbage yield and dry weight of plant were obtained by using $100 \% \mathrm{~K}$ and $75 \% \mathrm{NP}$ along with Azotobacter, Azospirillum and PSB) which was significantly superior to the rest of the treatment combinations with respect to all characters taken under investigation. By substitution of $25 \%$ of inorganic fertilizer with biofertilizers can lower the cost of cultivation with little saving of the fertilizer cost. Basal application of FYM @ 5 t/ha at the last ploughing along with $75 \%$ of the recommended dose of fertilizer (i.e. 20:30:20) and soil inoculation with biofertilizers like Azotobactor, Azospirillum and PSB at the rate of $12 \mathrm{~kg} / \mathrm{hectare}$ is recommended to achieve 
the maximum potential yield of coriander cultivar Surabhi in the coastal agro climate of Odisha.

\section{References}

Choudhary, G.R., and Jat, N.L. 2004. Response of coriander (Coriandrum sativum) to inorganic nitrogen, farm yard biofertilizer, Indian J. Agric. Sci., 78: 761-763.

Gomez, K.A., and Gomez, A.A. 1984. Statistical procedures for agricultural research $\left(2^{\text {nd }}\right.$ edition) published by IRRI, Phillipines.

Hamte, V., Chtterjee, R., and Tania, C. 2013. Growth,flowering, fruit setting and maturity behavior of coriander with organics including biofertilisers and inorganics, The Bioscan, 8(3): 791-793.

Ilyas, M. 1980. Spices in India 3, Economic Bot., 34: 236-259.

Koocheki, A., Tabrizi, L., Ghorbani, R. 2009. Effect of biofertilizerson agronomic and quality criteria of Hyssop (Hyssopus officinalis). Iranian J. Agron. Res., 6(1): 127-137.

Kumar, T.S., Swaminathan, V. and Kumar, S. 2009. Influence ofnitrogen, phosphorus and biofertilizers on growth, yield and essentialoil constituents in ratoon crop of davana (Artemisia pallens Wall.). Electronic J. Environ. Agric. Food Chem., 8(2): 86-95.

Lamberts, M. 1990. Latin American vegetables, Advances in New Crops, 378-387.

Mahfouz, S.A., Sharaf, Eldin, M.A. 2007. Effect of mineral vs. biofertilizer on growth, yield, and essential oil content of fennel (Foeniculum vulgare Mill). Internat. Agrophyisics, 21(4): 361-366.

Migahed, H.A., Ahmed, A.E. and Abdel Ghany, B.F. 2004. Effect of different bacterial strains as biofertilizer agents on growth, production and oil of Apium graveolens under calcareous soil. Arab Univ. J. Agric. Sci., 12(2): 511-525.

Nagar, R.K., Muera, B.S., and Dadheech, R.C. 2009. Effet of weed and nutrient management on growth yield and quality of coriander (Coriandrum sativum L.), Indian J. Weed Sci., 41(3 and 4): 183-188.

Page, A.L., Miller, R.H., and Keeny, D.R. 1982. Methods of soil and plant analysis, part$2,2^{\text {nd }}$ Edn. No (9) Part in the series, American Society of Agronomy, Inc. Soil Sci. Society of American J., Madison, Wisconsin, U.S.A.

Piper, C.S. 1966. Soil and Plant Analysis, Hans Publisher, Bombay, 338.

Sahu, R.L., Sahu, H., and Kashyap, P. 2013. Effects of biofertilizer on the growth characters, yield attributes and quality of coriander (Coriandrum sativum). Asian J. Soil Sci., 8(2): 330-333.

Salem, A.G. and Awad, A.M. 2005. Response of coriander plants to organic and mineral fertilizers fertigated in sandy soils. Egyptian J. Agric. Res., 83(2): 829-858.

Singh, Ranjit and Rai, R.K. 2004. yield attributes, yield and quality of soybean (Glycine max) as influenced by integrated nutrient management. Indian J. Agron., 49(2): 271274.

Singh, S., Buttar, G.S., Singh, S.P. and Brar, D.S. 2005. Effect ofdifferent dates of sowing and row spacings on yield of fenugreek (Trigonella foenum gracum). J. Medi. Aromatic Plant Sci., 27(4): 629-630.

Tripathi M.L., Singh, H., and Chouhan, S.V.S. 2013. Response of coriander (coriandrum sativum) to integrated nutrient management, Technofame, 2(2): 43-46.

Valadabadi, S.A. and Farahani, H.A. 2011. Investigation of biofertilizers influence on quantity and quality characteristics in Nigella sativa L., J. Hort. Forestry, 3(3): 88-92.

\section{How to cite this article:}

Priyadarshini Jhankar, C.M. Panda and Debadatta Sethi. 2017. Effect of INM Practices on Yield, Yield Attributes and Economics of Coriander (Coriandrum sativum L.). Int.J.Curr.Microbiol.App.Sci. 6(5): 1306-1312. doi: https://doi.org/10.20546/ijcmas.2017.605.141 